Brazilian Journal
of Chemical
Engineering

ISSN 0104-6632

Printed in Brazil

www.abeq.org.br/bjche

Vol. 29, No. 01, pp. 87 - 98, January - March, 2012

\title{
PHENOL DEGRADATION IN AN ANAEROBIC FLUIDIZED BED REACTOR PACKED WITH LOW DENSITY SUPPORT MATERIALS
}

\author{
G. P. Sancinetti ${ }^{\text {* }}$, L. T. Sader ${ }^{2}$, M. B. A. Varesche ${ }^{3}$, E. L. C. Amorim ${ }^{3}$, \\ S. P. F. Omena ${ }^{3}$ and E. L. Silva ${ }^{2}$ \\ ${ }^{1}$ Institute of Science and Technology, Federal University of Alfenas, Phone + (55) (35) 3715-5922, \\ Rod. José Aurélio Vilela, 11999, CEP: 37715-400, Poços de Caldas - MG, Brazil. \\ E-mail: giselle.sancinetti@unifal-mg.edu.br \\ ${ }^{2}$ Department of Chemical Engineering, Federal University of São Carlos, \\ Rod. Washington Luis km 235, CEP: 13565-905, São Carlos - SP, Brazil. \\ ${ }^{3}$ Department of Hydraulic and Sanitation, University of São Paulo, \\ Av. Trabalhador Sãocarlense 400, CEP: 13566-590, São Carlos - SP, Brazil.
}

(Submitted: January 18, 2011 ; Revised: August 24, 2011 ; Accepted: August 29, 2011)

\begin{abstract}
The objective of this research was to study phenol degradation in anaerobic fluidized bed reactors (AFBR) packed with polymeric particulate supports (polystyrene - PS, polyethylene terephthalate - PET, and polyvinyl chloride - PVC). The reactors were operated with a hydraulic retention time (HRT) of $24 \mathrm{~h}$. The influent phenol concentration in the AFBR varied from 100 to $400 \mathrm{mg} \mathrm{L}^{-1}$, resulting in phenol removal efficiencies of $\sim 100 \%$. The formation of extracellular polymeric substances yielded better results with the PVC particles; however, deformations in these particles proved detrimental to reactor operation. PS was found to be the best support for biomass attachment in an AFBR for phenol removal. The AFBR loaded with PS was operated to analyze the performance and stability for phenol removal at feed concentrations ranging from 50 to $500 \mathrm{mg} \mathrm{L}^{-1}$. The phenol removal efficiency ranged from $90-100 \%$.

Keywords: Phenol; Anaerobic fluidized bed reactor; Biofilm; Polymeric particles.
\end{abstract}

\section{INTRODUCTION}

Phenol and phenolic compounds are present in wastewater from industries such as coal gasification, coke production, manufacture of synthetic chemicals, pharmaceuticals, pesticides, fertilizers, and dyes, and pulp and paper processes (Tay et al., 2001, Veeresh et al., 2005). Phenol and phenolic compounds are also used in the preparation of synthetic resins, antiseptics, dyes, biocides, photographic chemicals, and more (Sá and Boaventura, 2001, Fang et al., 2004). Wastewater that contains phenols and other toxic compounds requires careful treatment before discharge into a receiving water body. Phenol is either toxic (reduces enzymatic activity) or lethal to fish at relatively low concentrations. It imparts objectionable tastes to municipal drinking water, especially chlorinated water, even at very low concentrations (Hosseini and Borghei, 2005). Brazilian legislation has established a phenol concentration of $0.5 \mathrm{mg} \mathrm{L}^{-1}$ as the limit for wastewater discharge into natural water bodies or municipal sewerage systems. For drinking water, the World Health Organization prescribed a guideline concentration of $0.001 \mathrm{mg} \mathrm{L}^{-1}$ (WHO, 1994).

Recovery of phenols is economical at high concentrations by physical processes (e.g., solvent extraction or activated carbon adsorption). At intermediate concentrations, i.e., phenol concentrations ranging from 5 to $500 \mathrm{mg} \mathrm{L}^{-1}$, biological oxidation

*To whom correspondence should be addressed 
techniques are feasible (Veeresh et al., 2005). Phenol is biodegradable both aerobically (Sá and Boaventura, 2001, Hosseini and Borghesi, 2005, Tziotzios et al., 2005) and anaerobically (Tay et al., 2001, Fang et al., 2004, Wang et al., 1986, Bolaños et al., 2001, Farooqi et al., 2007).

The anaerobic degradation of phenol offers the advantages of having no oxygen requirement, producing low waste biomass, and generating a valuable waste product, methane gas. Different reactors have been evaluated for the anaerobic treatment of wastewater, both in suspended cultures (e.g., anaerobic digesters) and immobilized ones (e.g., anaerobic filter, expanded bed, and fluidized bed) (Rajeshwari et al., 2000). There has been an increasing interest in the immobilization of microorganisms on inert supports, since this strategy often leads to a more efficient process.

The removal of phenols has been accomplished using anaerobic filters (Khan et al., 1981), expanded bed reactors (Wang et al., 1986), and horizontal flow anaerobic immobilized biomass (HAIB) reactors (Bolaños et al., 2001). However, anaerobic treatment of phenol-containing wastewater has generally been carried out using UASB reactors (Tay et al., 2001, Veeresh et al., 2005, Fang et al., 2004, Farooqi et al., 2007).

The advantage of using anaerobic fluidized bed reactors (AFBR) for the treatment of hazardous waste with inhibitory or recalcitrant compositions has been recently demonstrated (Alvarez et al., 2006, Perez et al., 2007, Haroun and Idris, 2009). One factor that contributes to the efficiency of the fluidized bed process is the minimal liquid film diffusional resistance, which is attributed to the particle motion and liquid velocities. Another factor is the initial dilution of the influent, which provides alkalinity and some neutralization, reduces substrate concentration (important for high COD (chemical oxygen demand) wastes), and contributes to reduction of the shock effect of toxicant spikes (Hickey and Owens, 1981, Iza, 1991).

One of the most important aspects in the design of an AFBR is the choice of support material. The selection of appropriate support material should consider several aspects aside from those related to fluidization; experimental trials to determine the best material are unavoidable. Other considerations relate to the cost of the material and its physical properties (size, shape, particle density, hardness, rugosity and surface area) (Marin et al., 1999).

The particles most often used as supports in fluidized bed reactors are sand and activated charcoal. Sand is a cheap material and insensitive to abrasion.
Meanwhile, activated charcoal is more expensive and requires care with respect to abrasion because turbulence in the system can easily reduce the charcoal in size. Since fluidization of conventional supports usually requires high pump energy, the use of a low density support, such as polymeric particles, previously subjected to chemical treatment, can also improve upon the inherent advantages of fluidized bed bioreactors (Tavares et al., 1994, Tavares et al., 1995, Saucedo-Terán et al., 2004).

However, it is critical that the particulate media used be conducive to a rapid and extensive colonization of firmly attached biomass to assure that stable AFBR performance is attainable shortly after startup. Although the mechanisms and substances involved in adhesion and biofilm formation are not completely known, most studies have emphasized that extracellular polymeric substances (EPS) are the main material responsible for the structural and functional integrity of biofilms due to the cohesive forces they exert, which are responsible for keeping cells together in the form of biofilms, flocs and sludge (Tavares et al., 1995, Flemming and Wingender, 2001, Qureshi et al., 2005).

To date, few systematic studies have compared the startup and steady state performances of AFBR containing different types of support media under similar operating conditions. Therefore, the present study focused on phenol removal by a mixed culture growing on polystyrene, polyethylene terephthalate, or polyvinyl chloride as support materials in AFBR. The biofilms formed on the support materials were evaluated based upon a quantification of the biomass and extracellular polymers. The effects of phenol concentration on the performance of the AFBR and its stability were also investigated.

\section{MATERIALS AND METHODS}

\section{Synthetic Wastewater and Inoculum}

The reactor was operated with a synthetic substrate containing phenol as the sole carbon source. The phenol concentrations for treatment ranged from 50 to $500 \mathrm{mg} \mathrm{L}^{-1}$, plus the following nutrients (in $\mathrm{mg} \mathrm{L}^{-1}$ ): $\mathrm{NH}_{2} \mathrm{CONH}_{2}, 62.5 ; \mathrm{NiSO}_{4} \cdot 7 \mathrm{H}_{2} \mathrm{O}, 0.5 ; \mathrm{FeSO}_{4} \cdot 7 \mathrm{H}_{2} \mathrm{O}, 2.5$; $\mathrm{FeCl}_{3} \cdot 6 \mathrm{H}_{2} \mathrm{O}, 0.25 ; \mathrm{CaCl}_{2} \cdot 2 \mathrm{H}_{2} \mathrm{O}, 23.5 ; \mathrm{CoCl}_{2} \cdot 6 \mathrm{H}_{2} \mathrm{O}$, $0.04 ; \mathrm{SeO}_{2}, 0.035 ; \mathrm{KH}_{2} \mathrm{PO}_{4}, 42.5 ; \mathrm{K}_{2} \mathrm{HPO}_{4}, 10.85$; $\mathrm{Na}_{2} \mathrm{HPO}_{4} \cdot 7 \mathrm{H}_{2} \mathrm{O}, 16.7 ; \mathrm{NaHCO}_{3}, 1,000$; and yeast extract, 300. The inoculum was obtained from the anaerobic sludge of a UASB reactor treating effluent from a swine slaughterhouse (volatile suspended solids (VSS) $\sim 20 \mathrm{~g} \mathrm{~L}^{-1}$ ). 
Evaluation of Anaerobic Phenol Degradation in Batch Reactors

The experiments for evaluating the potential of the mixed culture for anaerobic phenol degradation were performed in a shaking incubator. Duran bottles of $2 \mathrm{~L}$, with a working volume of $1 \mathrm{~L}$, were used as anaerobic batch reactors. Besides phenol and nutrient additions, $10 \%(\mathrm{v} / \mathrm{v})$ of inoculum (total volatile solids (TVS) $\sim 960 \mathrm{mg} \mathrm{L}^{-1}$ ) was fed into the Duran bottles; the initial $\mathrm{pH}$ was 6.8. The headspace of the bottle was purged with $\mathrm{N}_{2}(100 \%)$ for 60 seconds. The rubber topped bottles were set in a shaking incubator adjusted to $30^{\circ} \mathrm{C}$ and $150 \mathrm{rpm}$. The concentrations of phenol studied were 137 and $355 \mathrm{mg} \mathrm{L}^{-1}$. The experiments were performed in duplicate.

\section{Support Material for Immobilization of the Anaerobic Sludge}

Particles of polystyrene (PS), polyethylene terephthalate (PET), and polyvinyl chloride (PVC) were used in the AFBR as support materials for biomass immobilization. The PS, PET and PVC particles were submitted to a prior chemical treatment to improve their surface characteristics (rugosity, porosity and electrical charge) as reported by Tavares et al. (1994, 1995) and Saucedo-Terán et al. (2004). This procedure provided better conditions for the microorganism's attachment. This chemical treatment consisted of submerging PS and PET particles in a sulfochromic acid solution for 50 minutes, rinsing them in water, submerging them in concentrated nitric acid for 20 minutes, rinsing them in water again, and finally drying them in an oven at $40^{\circ} \mathrm{C}$ (Tavares et al., 1994, 1995). However, this procedure was applied four times for the polystyrene particles, identical to the procedure used by Sancinetti (2004), who observed the gradual increase in the presence of particles roughness under an optical and scanning microscope.

PET particles suffered the same treatment as polystyrene particles however there was a $30 \%$ mass loss of these particles, without the need of another acid bath. After dipping in sulphochromic acid, the PVC particles became soft and dark colored. It was therefore decided to submerge them in concentrated nitric acid for 20 minutes only once. The PVC particles were rinsed in water and dried in an oven at $40^{\circ} \mathrm{C}$. The main characteristics of the support materials are shown in Table 1.
Table 1: Characteristics of the support materials

\begin{tabular}{|l|r|r|r|}
\hline & \multicolumn{1}{|c|}{ PS } & \multicolumn{1}{|c|}{ PET } & \multicolumn{1}{c|}{ PVC } \\
\hline Size $(\mathrm{mm})$ & $2.5 \times 2.5$ & $3.0 \times 3.0$ & $3.0 \times 3.0$ \\
Density $\left(\mathrm{g} \mathrm{cm}^{-3}\right)$ & 1.05 & 1.25 & 1.11 \\
Shape & cylinders & cylinders & cylinders \\
Weight of support & 190 & 226 & 200 \\
material loaded $(\mathrm{g})$ & & & \\
Height of fixed bed $(\mathrm{cm})$ & 34 & 30.5 & 31 \\
Minimum fluidization & 0.74 & 1.35 & 1.16 \\
velocity $\left(\mathrm{cm} \mathrm{s}^{-1}\right)$ & & & \\
\hline
\end{tabular}

\section{Anaerobic Fluidized Bed Reactors}

Figure 1 shows the schematic of the three identical reactors used for evaluating the low density supports in AFBR. The reactors used for the experimental work were constructed of an $80.0 \mathrm{~cm}$ long, $3.5 \mathrm{~cm}$ internal diameter acrylic tube. This inner tube was enclosed in an outer jacket through which water was circulated to maintain the temperature of the reactor at $30 \pm 1^{\circ} \mathrm{C}$. Three sampling points were installed along the reactor length to obtain liquid and bioparticle samples. At the top of the reactor, a stainless steel screen was installed to prevent the escape of particles. A liquid displacement system was used to measure the amount of biogas generated, as shown in Figure 1.

The useful volume of the reactor with polystyrene particles was $606 \mathrm{~cm}^{3}$, with PET particles was $332 \mathrm{~cm}^{3}$ and in the reactor with PVC particles was $578 \mathrm{~cm}^{3}$.

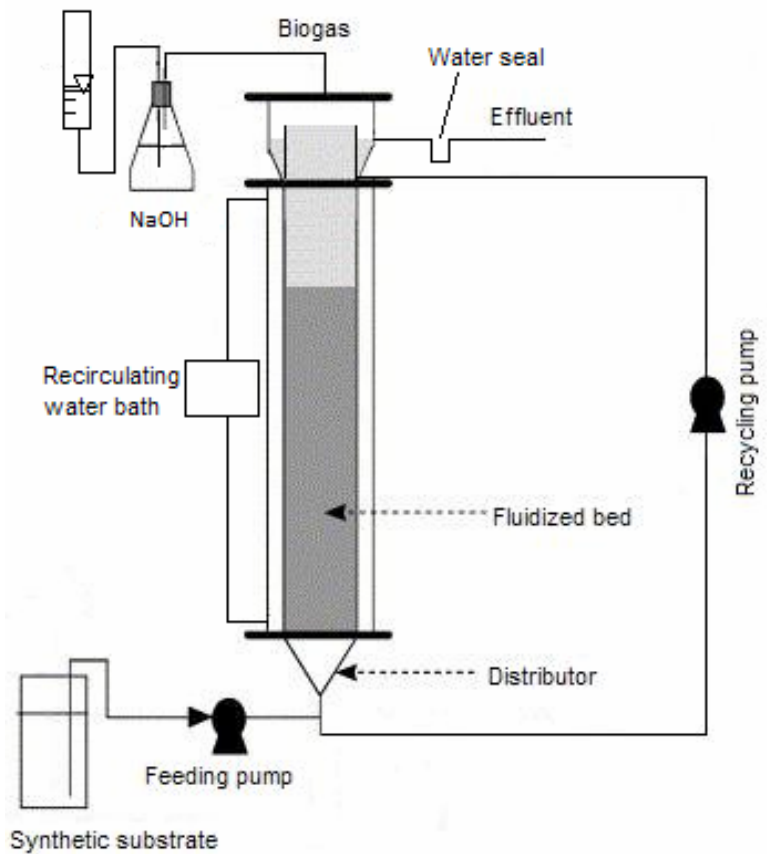

Figure 1: Schematic representation of the AFBR. 
Startup and Operational Conditions of the AFBR

The three reactors were packed with different support materials (PS, PET, or PVC), inoculated, and started up simultaneously under identical conditions. The AFBR were fed with synthetic wastewater containing phenol (100 mg $\mathrm{L}^{-1}$ ), nutrients, and inoculum adapted to phenol for approximately 40 days at a concentration of $460 \mathrm{mg}^{\text {TVS L }}{ }^{-1}$. The headspace of the AFBR was flushed with $\mathrm{N}_{2}(100 \%)$ for 180 seconds. The reactors remained at rest for 18 hours. After that, the AFBR were maintained under total recycle for seven days to promote the growth and attachment of biomass on the support materials; they were then switched to continuous mode with a designated HRT of $24 \mathrm{~h}$. Effluent recycle was maintained at a rate corresponding to 1.3 times the minimum fluidization flow rate of each support material in order to achieve completely mixed conditions within the reactor. The total volatile solids concentration after seven days of recirculation was $580 \mathrm{mg} \mathrm{TVS} \mathrm{L}^{-1}$, indicating an increase of the microbiological populations during the immobilization phase. The influent phenol concentration varied from 100 to $400 \mathrm{mg} \mathrm{L}^{-1}$.

After selecting the best polymeric particle, one system was operated to analyze the performance and stability of the AFBR for phenol removal. To simplify the analysis of the results, the research was divided into eight experimental phases, corresponding to different values of phenol concentration for an HRT of $24 \mathrm{~h}$. When a steady state was reached, the phenol concentration was increased progressively from 50 to approximately $500 \mathrm{mg} \mathrm{L}^{-1}$. The reactor was operated for 116 days in total.

\section{Chemical and Microbiological Analyses}

Phenol analysis was performed using the 4aminoantipyrine colorimetric method (APHA, 1998). COD, TVS, VSS and $\mathrm{pH}$ values were measured according to the Standard Methods (APHA, 1998). Alkalinity, as $\mathrm{CaCO}_{3}$, was determined as described by Dillalo and Albertson (1961) and adapted by Ripley et al. (1986). Volatile fatty acids (VFA) concentrations were assessed using gas chromatography (HP 6890/FID) equipped with a $30 \mathrm{~m}$ long HP INNOWAX column, with an internal diameter of $0.25 \mathrm{~mm}$ and a film thickness of $0.25 \mu \mathrm{m}$. The injector temperature was kept at $250^{\circ} \mathrm{C}$; the oven was maintained at $100^{\circ} \mathrm{C}$ for $3 \mathrm{~min}$, after which it was heated at a rate of $5^{\circ} \mathrm{C} / \mathrm{min}$ to $180^{\circ} \mathrm{C}$ and kept at that temperature for $5 \mathrm{~min}$ (Moraes et al., 2000).
Structural analysis of biofilm samples was performed by using a Zeiss DSM-960 digital scanning microscope (Varesche et al., 1997). Biomass adhesion to the polymeric particles was determined according to the methods of Chen and Chen (2000). Quantification of the extracellular polymeric substances (EPSs) in protein form was performed in accordance with the method proposed by Lowry et al. (1951) and modified by Peterson (1977), using bovine serum albumin as a standard. Analysis of EPSs in the carbohydrate form was carried out according to the methods of Dubois et al. (1956) using lactose as a standard.

\section{RESULTS AND DISCUSSION}

\section{Evaluation of Anaerobic Phenol Degradation by the Mixed Culture in Batch Reactors}

As mentioned above, the condition of $10 \%$ sludge in batch reactors was adopted for the initial experiments, and the initial biomass concentration was $960 \mathrm{mg} \mathrm{TVS} \mathrm{L}^{-1}$. As can be seen from Figure 2, the results accompanied total phenol consumption over 423 hours (17 days) and 871 hours (36 days) for the tests with 137 and $355 \mathrm{mg}$ phenol $\mathrm{L}^{-1}$, respectively. Figure 2 shows the average value of two experiments for each phenol concentration and the deviation of the data. The solids concentrations in the batch reactors increased to 140 and $220 \mathrm{mg} \mathrm{TVS} \mathrm{L}^{-1}$ for phenol concentrations of 137 and $355 \mathrm{mg} \mathrm{L}^{-1}$, respectively, which indicated the formation of an active biomass in the batch reactors. The final $\mathrm{pH}$ was within the normal range of anaerobic system operation, between 7.2-7.4 (Speece, 1996).

Increased acetic acid production was observed in experiments with concentrations of 137 and $355 \mathrm{mg}$ phenol $\mathrm{L}^{-1}$. As can be seen in Figure 3, the acetic acid remained at the end of the bioassay and was beginning to be consumed; it is likely that, given time, all of the acetate would have been converted into methane. The degradation of phenol by fermentative methanogenic consortia is well established. Phenol is first carboxylated to p-hydroxybenzoic acid. This compound is next dehydroxylated to benzoic acid, which is then reduced, cleaved and transformed into acetate and propionate and ultimately methane (Ramakrishnam and Gupta, 2006).

Therefore, the gradual adaptation of the microbial consortium to phenol for a period of approximately 40 days in the anaerobic batch reactors secured the establishment of inoculum for the startup of the AFBR. 


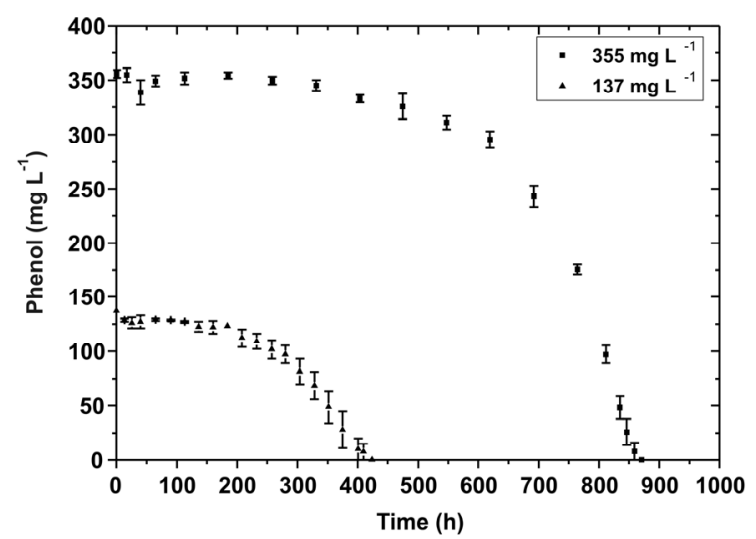

Figure 2: Temporal variation of the phenol concentration.

\section{Effect of Phenol Concentration on the Performance of AFBR Packed with Polymeric Particles}

After the adaptation of the inoculum to phenol in anaerobic batch reactors, $1.3 \mathrm{~L}$ of adapted sludge supplemented with nutrient solution was used to start up each of the AFBR. As can be seen in Figures 4 to 6, the startup of the AFBR was fast. Steady state conditions were reached after three days of continuous operation at $100 \mathrm{mg} \mathrm{L}^{-1}$, with a phenol removal efficiency of $100 \%$. The average removal of phenol was close to $100 \%$ at an influent phenol concentration of $400 \mathrm{mg} \mathrm{L}^{-1}$ with each of the three support materials tested.

For the AFBR containing PVC, an instability appeared in the phenol removal efficiency on the $45^{\text {th }}$ day, which remained until the end of the continuous operation of this reactor. This instability was attributed

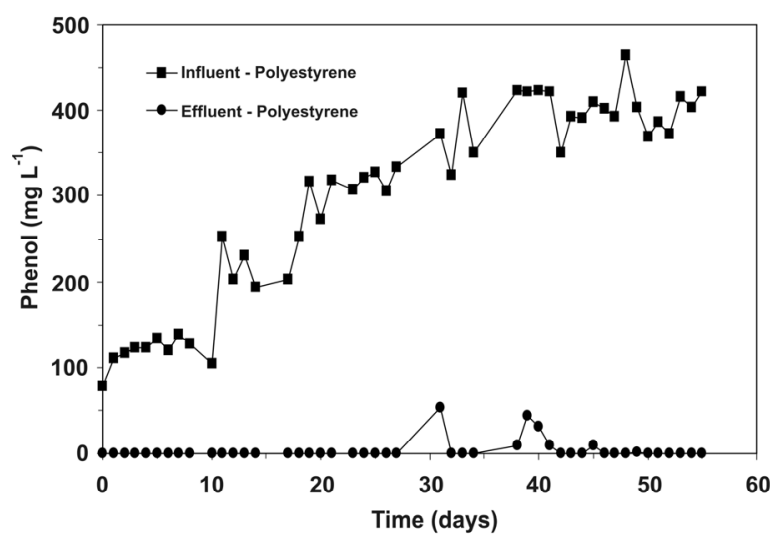

Figure 4: Variation of the phenol concentration in the AFBR containing PS over the operating period.

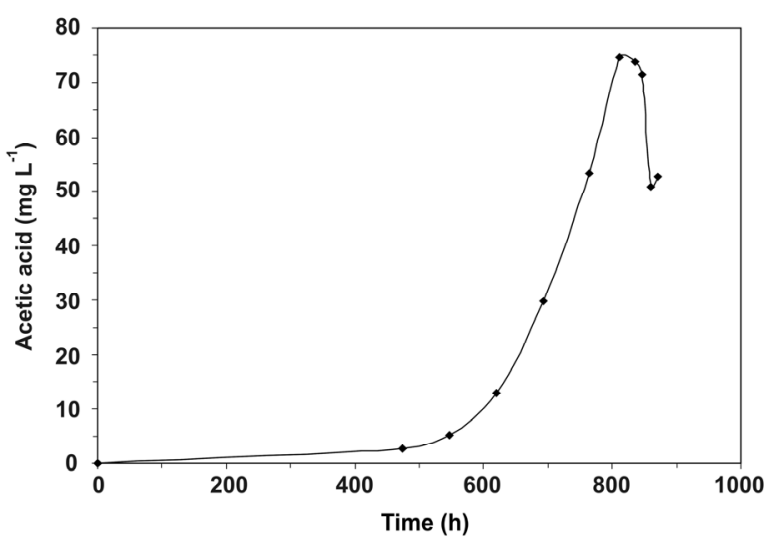

Figure 3: Temporal variation of acetic acid production for the experiment with $355 \mathrm{mg}$ phenol L ${ }^{-1}$.

to the deformation of the PVC particles from the $10^{\text {th }}$ day onward, which caused increases in the roughness and size of the support material, favoring microbial adhesion. The deformation of the PVC particles led to bed stratification in the AFBR and increased biofilm thickness; bed stratification has many negative effects on fluidized bed reactor performance.

Thicker biofilms pose diffusion limitations and washout problems. Stratification can be attributed to the influence of a biofilm on the settling velocity of the particles. The presence of a biofilm coating decreases the overall particle density, thereby increasing its buoyancy. The biofilm also increases the particle's size, thereby increasing the drag force exerted on it by the liquid flowing upward. The particles in a fluidized bed are expected to segregate according to size and mean density (Saravanan and Sreekrishnan, 2006).

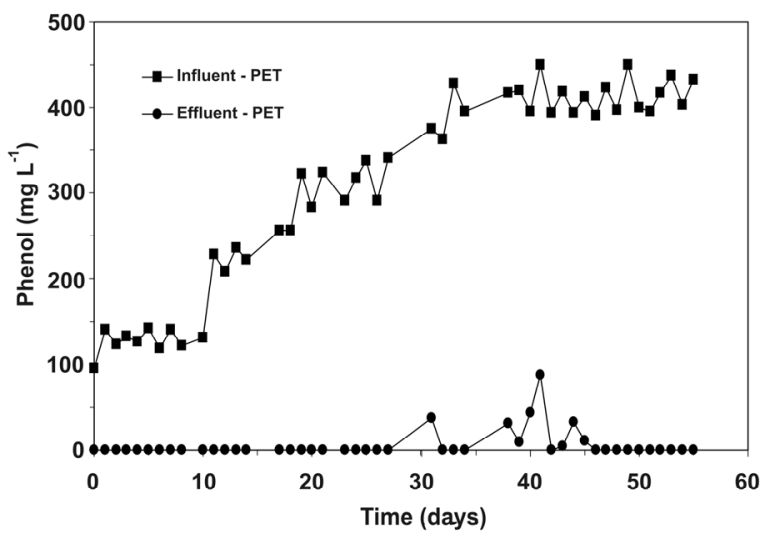

Figure 5: Variation of the phenol concentration in the AFBR containing PET over the operating period. 


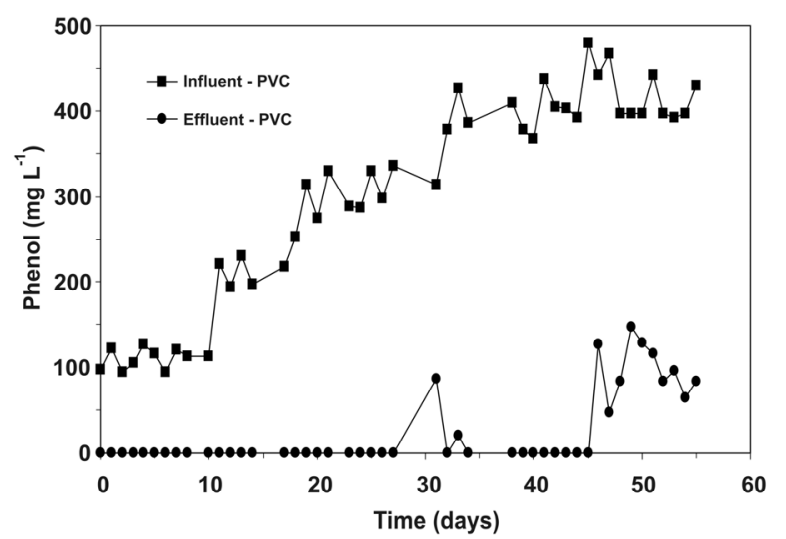

Figure 6: Variation of the phenol concentration in the AFBR containing PVC over the operating period.

The results obtained for the AFBR containing PVC were in accordance with those of Hidalgo and García-Encina (2002), who observed that a decrease of the expansion provoked a biomass increase in the reactor and a decrease in the removal rate of organic matter. This can be explained by a mass transfer limitation phenomenon, because substrate utilization rates, related to diffusional resistance, are strongly dependent on the reactor mixing intensity. Volatile fatty acids accumulated within the system when the expansion of the fluidized bed was lower than $10 \%$.

The EPS development on the support materials did not affect the stability of the AFBR containing PS and PET, leading to slight increases in the bed heights of these AFBR. Figures 7 to 9 show the variations in TVS contents, EPS contents in the form of carbohydrates, and EPS contents in the form of proteins, respectively, in the biomass attached to PS, PET, and PVC particles as a function of continuous operation time of the AFBR. Attached biomass was higher for PVC particles, while EPS content in carbohydrates and proteins was greater for polystyrene particles. The initial decrease in the TVS/support ratio in the AFBR can be attributed to the batch operation mode during the first seven days to favor biomass growth and attachment on the support materials before switching to the continuous mode; after this initial period, there was an increase in the attached biomass in the AFBR.

The higher EPS content in the PVC particles compared to the PS and PET particles could be related to the thicker biofilm and bed stratification. In the AFBR containing PS and PET, neither particle deformation nor bed stratification occurred. However, these reactors had slight increases in the attached biomass from the $20^{\text {th }}$ day of continuous operation onward, while the EPS contents in the AFBR containing PS and PET remained almost constant.

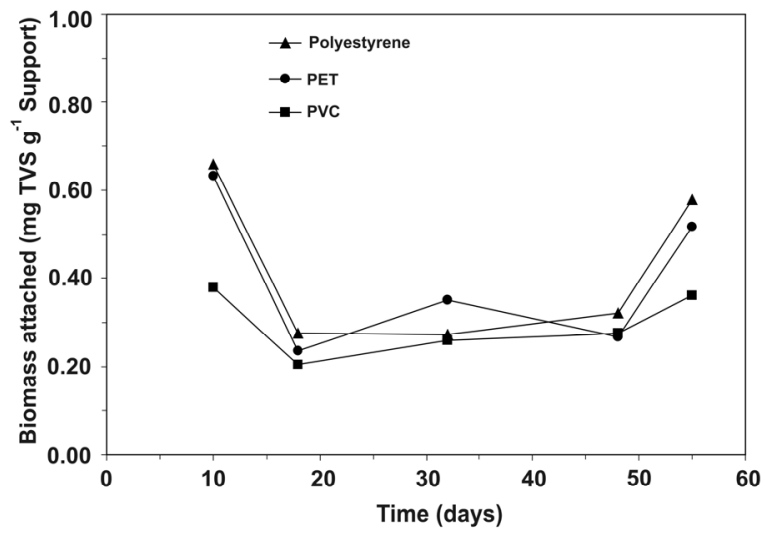

Figure 7: Attached biomass in the AFBR.

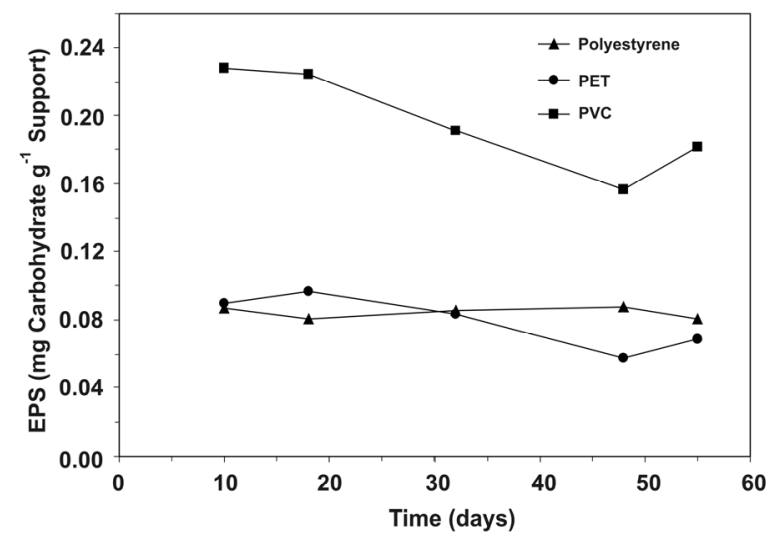

Figure 8: EPS content in the carbohydrate form in the AFBR. 


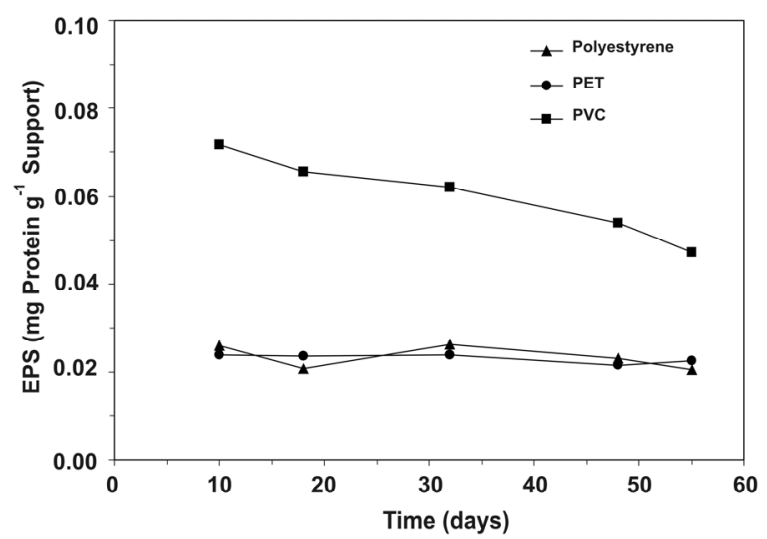

Figure 9: EPS content in the protein form in the AFBR.

According to Kuroda et al. (1988), the formation of the biofilm depends not only on the characteristics of the biomass and fluid regimes, but also on the characteristics of the solid supports. However, in biofilm reactors, detachment is the most important process for balancing growth and removal of the excess biomass. Detachment controls the solid residence time of the microorganisms, which in turn influences the overall performance and stability of the bioreactor (Derlon et al., 2008).

Microbiological characterizations of the biofilms on the support materials were performed periodically through scanning electron microscopy (SEM) micrographs. Figure 10 shows the predominant presence of straight, oval, and spiral bacilli, vibrio, and cocci in the AFBR containing polymeric particles. Figure 10a shows the predominance of rods adhered to the PS particles. On the PET particles (Figure 10b), the presence of straight rods, oval rods, and curved rods also were observed. Figure $10 \mathrm{c}$ also shows bacteria with morphologies similar to rods and cocci adhering to the PVC particles.

\section{Stability of Phenol Removal in AFBR Packed with Polystyrene Particles}

Although the AFBR packed with PS and PET particles showed similar good results for phenol degradation (organic loading removals of 0.84 and $0.98 \mathrm{~kg}$ phenol m $\mathrm{d}^{-1}$, respectively), the authors of this study chose PS as the best support material for biomass attachment in AFBR for phenol removal because it has the lowest density (Table 1), reducing the energy costs for pumping.

The $100 \%$ removal efficiency confirmed that the reactor startup was fast and that a stationary state had been reached after three days of continuous operation at an influent phenol concentration of $50 \mathrm{mg} \mathrm{L}^{-1}$. The fast reactor response at the beginning of the operation was attributed to the fact that the system was kept as a closed circuit for the first seven days to promote microbial adhesion to the PS particles. The results obtained in this study were similar to the startup periods previously reported for biofilm reactors.

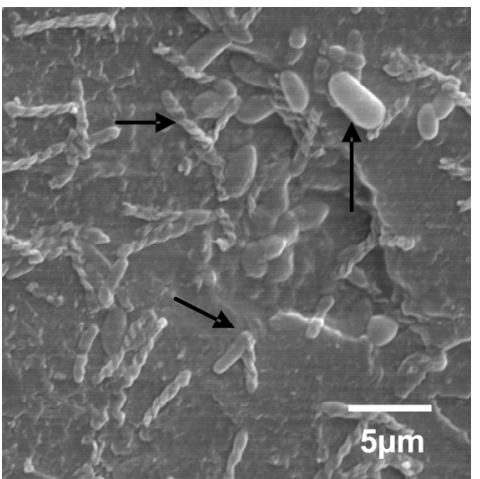

(a)

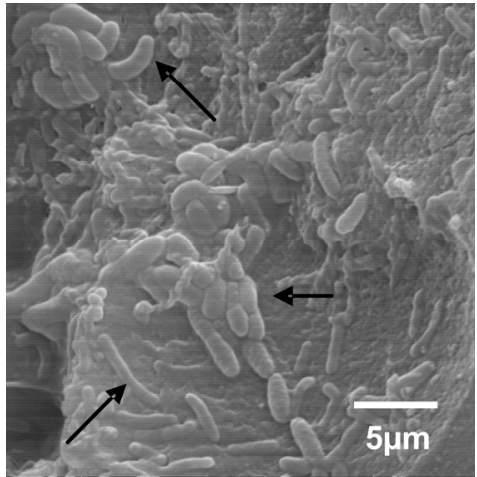

(b)

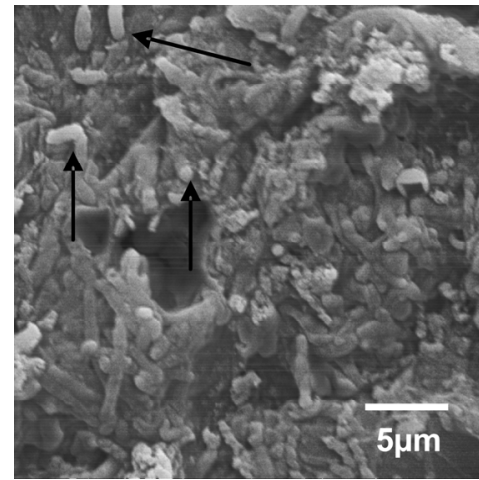

(c)

Figure 10: SEM micrographs of biomass attached to support material on the $55^{\text {th }}$ day of continuous operation: (a) PS, (b) PET, and (c) PVC (magnification 5,000X). 
In an expanded bed reactor containing granular activated charcoal (Wang et al., 1986), the startup period was eight days for a phenol concentration of $358 \mathrm{mg} \mathrm{L}^{-1}$. In a HAIB reactor packed with polyurethane foam (Bolaños et al., 2001), the startup period was 33 days for a phenol concentration of $50 \mathrm{mg} \mathrm{L}^{-1}$, with an average removal efficiency of $69 \%$. In a UASB reactor (Faaroqi et al., 2007), the startup period was 40 days for a phenol concentration of $200 \mathrm{mg} \mathrm{L}^{-1}$, with an average removal efficiency of $83 \%$.

Figure 11 shows the results obtained for influent and effluent phenol concentrations for all operational phases of the AFBR containing PS. Notably, the phenol removal efficiency was $100 \%$ for average influent phenol concentrations of 51.6 to $197.1 \mathrm{mg} \mathrm{L}^{-1}$ (operation phases I to III). When the concentration was increased to $308.5 \mathrm{mg} \mathrm{L}^{-1}$ (phase IV), the efficiency was $97 \%$ until the $25^{\text {th }}$ day. On the $25^{\text {th }}$ and $32^{\text {nd }}$ days, the phenol removal efficiencies decreased to $82 \%$ due to operational problems of the pumping systems, which increased the influent flow rate and thereby caused shock loads in the reactors. However, the AFBR quickly recovered their maximal phenol removal efficiency after organic load reduction through adjusting the influent flow rate to a value corresponding to an HRT of $24 \mathrm{~h}$. When the average influent phenol concentration in the AFBR was increased to $445.4 \mathrm{mg} \mathrm{L}^{-1}$, the phenol removal efficiency ranged from $91-100 \%$.

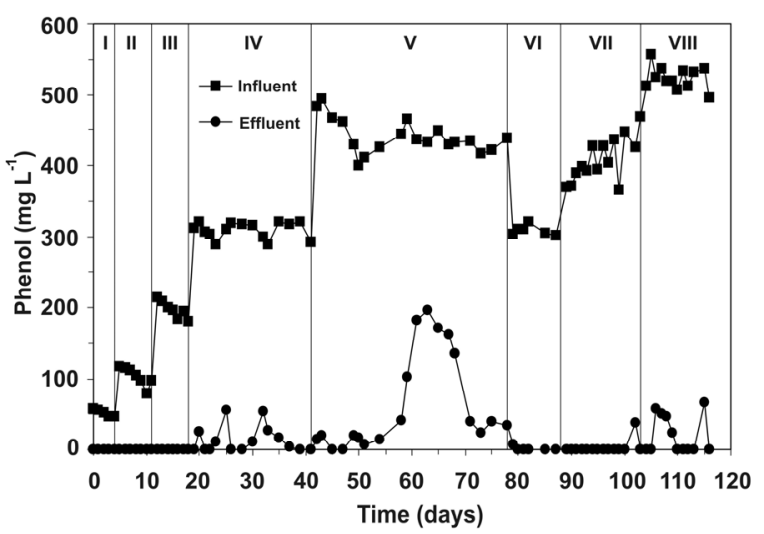

Figure 11: Variation of the phenol concentration with time in the PS reactor.

In order to test the stability of the AFBR containing PS, the influent flow rate was increased by $100 \%$ (decreasing the HRT to $12 \mathrm{~h}$ ) on the $56^{\text {th }}$ day and maintained for $48 \mathrm{~h}$ with an average influent phenol concentration of $440.3 \mathrm{mg} \mathrm{L}^{-1}$ (phase V). As can be seen in Figure 12, the phenol removal efficiency of the reactor decreased to $58 \%$; on the $71^{\text {st }}$ day, it returned to $91 \%$. Over the period from the $71^{\text {st }}$ to the $78^{\text {th }}$ day, an increasing amount of suspended biomass was observed in the effluent of the AFBR. According to Perez et al. (2007), in biofilm systems the amount of suspended biomass is negligible with respect to the attached biomass. This aspect allows low HRT levels to be maintained with respect to the suspended systems, and this causes the washing out of the suspended biomass (the fluidized bed retains the growth support media in suspension by drag forces exerted by upflowing wastewater). Therefore, the levels of suspended solids in the effluent arising from the detachment of biomass would be expected to be higher during periods when the applied organic loading rate was increased, whether due to an increase in influent flow rate or to a decrease of HRT. To ensure the complete recovery of the AFBR between days 79 and 87 (phase VI), the influent phenol concentration was reduced to an average of $307.8 \mathrm{mg} \mathrm{L}^{-1}$. Phenol removal efficiency returned to $100 \%$. As can be seen in Figure 11, during phase VII ( $89^{\text {th }}$ to $103^{\text {rd }}$ day), the average influent phenol concentration was increased to $408.1 \mathrm{mg} \mathrm{L}^{-1}$, and the phenol removal efficiency remained at $100 \%$. From the $103^{\text {rd }}$ day on, the average influent phenol concentration was increased to $523.4 \mathrm{mg} \mathrm{L}^{-1}$, and phenol removal efficiency ranged from $89-100 \%$.

The results obtained in this study indicated good performance for the AFBR containing PS particles up to phenol concentrations of approximately $500 \mathrm{mg} \mathrm{L}^{-1}$. The use of inoculum from swine manure previously adapted to phenol contributed positively to the fast AFBR startup, high phenol removal efficiencies, and reactor stability towards hydraulic loading shocks. The values of the phenol removal efficiencies were satisfactory and consistent with removal efficiencies of phenol in expanded bed reactors (Wang et al., 1986), HAIB reactors (Bolaños et al., 2001), and UASB reactors (Farooqi et al., 2007) with influent phenol concentrations up to $500 \mathrm{mg} \mathrm{L}^{-1}$.

The COD reduction efficiencies were $70 \%$ for phase I, $87 \%$ for phase II, 93\% for phase III, and $91 \%$ for phase IV. After the end of the hydraulic loading shock, the COD reduction efficiency returned to $95-100 \%$.

High COD reduction efficiency indicates that phenol was actually removed from the liquid phase not just converted to intermediate products. The VFA were detected by chromatography during reactor operation with $440.3 \mathrm{mg}$ phenol $\mathrm{L}^{-1}$ (phase $\mathrm{V})$. On day $58,15.48 \mathrm{mg} \mathrm{L}^{-1}$ of acetic acid was measured and on day $6169.28 \mathrm{mg} \mathrm{L}^{-1}$ of acetic acid, $21.11 \mathrm{mg} \mathrm{L}^{-1}$ of propionic acid and $4.22 \mathrm{mg} \mathrm{L}^{-1}$ of 
isovaleric acid were measured. The volatile acids presence on day 61 confirms the results of phenol concentration that indicated a decrease of reactor efficiency to $58 \%$. The analysis for the next period, phase VI, after the decrease of phenol concentration to $307.8 \mathrm{mg} \mathrm{L}^{-1}$, did not indicate volatile acids, proving the reactor recovery and system stability. During the operation of an anaerobic expanded bed reactor with activated carbon as the support material, Wang et al. (1986) observed that acetic acid was the only acid measured in the effluent and that its concentration rose with the increase of feed phenol concentration. For phenol concentrations up to $703 \mathrm{mg} \mathrm{L}^{-1}$, the effluent acetic acid concentration was lower than $2 \mathrm{mg} \mathrm{L}^{-1}$; nonetheless, for phenol concentrations of $1,492 \mathrm{mg} \mathrm{L}^{-1}$ and $2,959 \mathrm{mg} \mathrm{L}^{-1}$, the acetic acid concentrations were $22 \mathrm{mg} \mathrm{L}^{-1}$ and $374 \mathrm{mg} \mathrm{L}^{-1}$, respectively.

Even with the decrease in reactor efficiency during phases IV and $\mathrm{V}$, effluent $\mathrm{pH}$ variation was not observed. The $\mathrm{pH}$ stability may be due to the alkalinity generation, the absence of acidity generation, and the phenol removal efficiency, as phenol is a weak acid. The average values for effluent $\mathrm{pH}$ during the reactor operation were 8.61 for phase I, 8.5 for phase II, 8.6 for phase III, 8.1 for phase IV, 8.1 for phase V, 8.2 for phase VI, 8.0 for phase VII, and 7.9 for phase VIII. Fatty acid accumulation was not observed, probably due to phenol and COD usage and the values of $\mathrm{pH}$ and alkalinity observed.

Figure 12 shows the results for bicarbonate alkalinity concentrations at all phases of reactor operation. An initial decrease of effluent alkalinity concentration is evident from phase I until day 7 of phase II. This decrease can probably be attributed to maintenance of a closed system during the first seven days of the startup process. Even though the reactor nominally reached steady state after three days of continuous operation, the alkalinity stabilization occurred only in phase III. After phase II, median alkalinity concentration was $201.8 \mathrm{mg} \mathrm{L}^{-1}$; a gradual increase of effluent alkalinity concentration occurred in the other phases. The values obtained were $422.8 \mathrm{mg} \mathrm{L}^{-1}$ for phase III, $522.7 \mathrm{mg} \mathrm{L}^{-1}$ for phase IV, $521.8 \mathrm{mg} \mathrm{L}^{-1}$ for phase $\mathrm{V}, 550.0 \mathrm{mg} \mathrm{L}^{-1}$ for phase VI, $577.0 \mathrm{mg} \mathrm{L}^{-1}$ for phase VII, and $570.7 \mathrm{mg} \mathrm{L}^{-1}$ for phase VIII.

Only in phase I was the standard deviation higher than the average value of the effluent alkalinity, $590.0 \mathrm{mg} \mathrm{L}^{-1}$. This anomaly was due to the effluent alkalinity instability at the beginning of continuous reactor operation. Alkalinity was presumably generated because the effluent concentrations presented higher values than the influent alkalinity in all phases of reactor operation. Even after the hydraulic loading shock, the reactor operation at all phenol concentrations was stable with respect to bicarbonate alkalinity.

SEM micrographs of polystyrene particles at the end of each operational phase showed straight rods, oval rods and cocci (Figure 13). In this work, the microorganisms of the Domain Bacteria were responsible for the organic matter (phenol, organic acids such as propionate, butyrate and formate) degradation and, consequently, for the formation of acetic acid, that probably was used by acetoclastic Archaea (Methanosaeta).

The adopted methodology of acid pre-treatment of the polystyrene particles before being put inside the reactor was effective, as were the startup and reactor inoculation processes. An increase in microorganism adhesion to the surface and cavities of the polystyrene particles with operating time was observed in SEM micrographs. SEM micrographs confirmed that polystyrene particles can be used as support material for biofilm formation and development in AFBR.

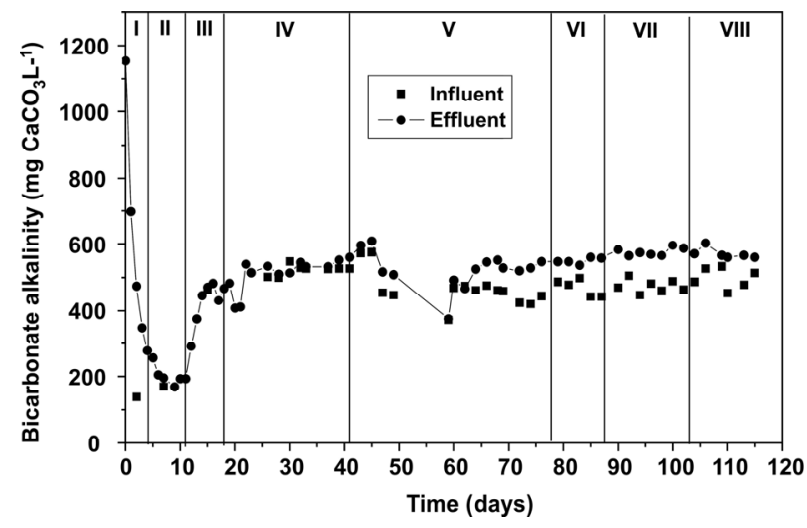

Figure 12: Bicarbonate alkalinity variation with time. 


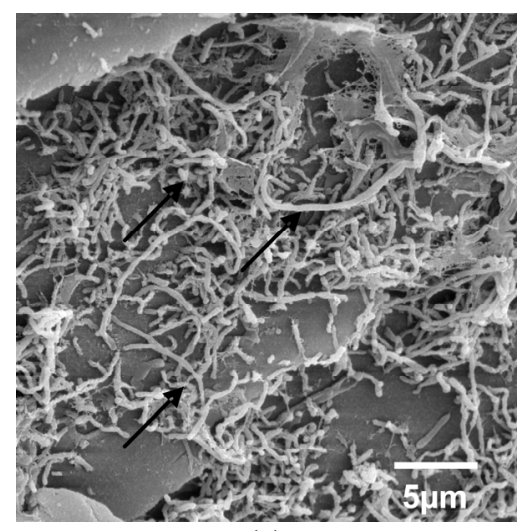

(a)

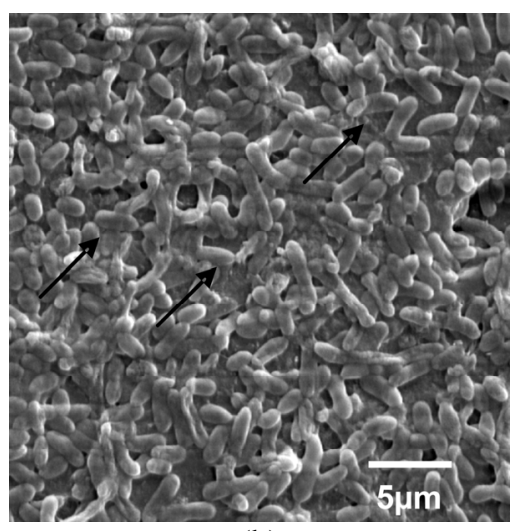

(b)

Figure 13: SEM micrographs: cell adhesion and biofilm formation on polystyrene particles. (a) Bacilli observed during phase $\mathrm{V}$, instability of the reactor (magnification 3,000X). (b) Bacilli forming polymeric matrix during phase VII (the end of experiment; magnification 5,000X).

\section{CONCLUSIONS}

The AFBR containing PS, PET, and PVC operated with removal efficiencies close to $100 \%$ at phenol concentrations up to $400 \mathrm{mg} \mathrm{L}^{-1}$. The methodology used to start the reactor was effective and the inoculum from swine manure proved to be a good source of microorganisms to perform anaerobic phenol degradation. PVC particles showed more attached extracellular polymeric substances than PET or PS; these substances caused stratification and loss of stability of the reactor after 40 days of operation. This phenomenon was attributed to deformation of the PVC particles during AFBR operation. Reactors filled with PET and PS particles showed stable performance; both have appropriate characteristics as supports in an AFBR. The reactor filled with PET particles showed better results in the degradation of phenol in relation to the reactor filled with PS. However, PS presents the best overall characteristics for the operation of AFBR reactors, especially its lower density, which reduces the energy cost of the pumping needed for large scale fluidization.

The reactor operated for a long period of time with phenol as the sole carbon source. Previously adapted inoculum contributed positively to the rapid response observed in the reactor, with high removal efficiencies for phenol and COD. In this test, the PS particles proved to be suitable for microbial adhesion and maintenance of the biological process, as indicated by the presence of straight rods, oval rods and cocci, which were associated with phenol removal. The anaerobic fluidized bed reactor yielded good performance with respect to phenol and COD removal from the synthetic wastewater used. The efficiency of phenol consumption was higher than $95 \%$ and COD reduction was higher than $85 \%$ for phenol concentrations up $500 \mathrm{mg} \mathrm{L}^{-1}$.

\section{ACKNOWLEDGEMENTS}

The authors acknowledge FAPESP, CAPES and $\mathrm{CNPq}$ for their financial support of this work.

\section{NOMENCLATURE}

\begin{tabular}{|c|c|c|}
\hline AFBR & $\begin{array}{l}\text { anaerobic fluidized bed } \\
\text { reactors }\end{array}$ & \\
\hline COD & chemical oxygen demand & $\mathrm{mg} \mathrm{L}^{-1}$ \\
\hline EPS & $\begin{array}{l}\text { extracellular polymeric } \\
\text { substances }\end{array}$ & \\
\hline FID & flame ionization detector & \\
\hline HAIB & $\begin{array}{l}\text { horizontal flow anaerobic } \\
\text { immobilized biomass } \\
\text { reactor }\end{array}$ & \\
\hline HRT & hydraulic retention time & $\mathrm{h}$ \\
\hline PS & polystyrene & \\
\hline PET & polyethylene terephthalate & \\
\hline PVC & polyvinyl chloride & \\
\hline SEM & $\begin{array}{l}\text { scanning electron } \\
\text { microscopy }\end{array}$ & \\
\hline TVS & total volatile solids & $\mathrm{mg} \mathrm{L}^{-1}$ \\
\hline UASB & $\begin{array}{l}\text { upflow anaerobic sludge } \\
\text { blanket reactor }\end{array}$ & \\
\hline
\end{tabular}


VFA Volatile fatty acids

VSS volatile suspended solids

\section{REFERENCES}

Alvarez Cuenca, M., Vezuli, J., Lohi, A. and Upreti, S. R., Anaerobic biodegradation of diesel fuelcontaminated wastewater in a fluidized bed reactor. Bioprocess Biosystems Engineering, 29, 29-37 (2006).

APHA, AWWA, WPCF, Standard methods for the examination for water and wastewater (20th Ed.), Washington, DC: American Public Health Association/American Water Works Association/ Water Environmental Federation (1998).

Bolaños, M. L. R., Varesche, M. B. A., Zaiat, M. and Foresti, E., Phenol degradation in horizontal-flow anaerobic immobilized biomass (HAIB) reactor under mesophilic conditions. Water Science \& Technology, 44, 167-174 (2001).

Chen, C. Y. and Chen, S. D., Biofilm characteristics in biological denitrification biofilm reactors. Water Science \& Technology, 41, (4), 147-154 (2000).

Derlon, N., Massé, A., Escudié, R., Bernet, N. and Paul, E., Stratification in the cohesion of biofilms grown under various environmental conditions. Water Research, 42, 2102-2110 (2008).

Dilallo, R. and Albertson, O. E., Volatile Acids by direct titration. Journal of Water Pollution Control Federation, 33, (4), 356-365 (1961).

Dubois, M., Gilles, K. A., Hamilton, J. K., Rebers, P. A. and Smith, F., Colorimetric method for determination of sugars and related substances. Analytical Biochemistry, 28, (3), 350-356 (1956).

Fang, H. H. P., Liu, Y., Ke, S. Z. and Zhang, T., Anaerobic degradation of phenol in wastewater at ambient temperature. Water Science and Technology, 49, (1), 95-102 (2004).

Farooqi, I. H., Basheer, F. and Isa, M. H., Codegradation of phenol and m-cresols by upflow anaerobic sludge blanket reactor. Water Science \& Technology, 56, (7), 73-79 (2007).

Flemming, H. C. and Wingender, J., Relevance of microbial extracellular polymeric substances (EPSs) - Part I: Structural and ecological aspects. Water Science \& Technology, 43, (6), 1-8 (2001).

Haroun, M. and Idris, A., Treatment of textile wastewater with an anaerobic fluidized bed reactor. Desalination, 237, 357-366 (2009).

Hickey, R. F. and Owens, R. W., Methane generation from high-strength industrial wastes with the anaerobic biological fluidized bed.
Biotechnology and Bioengineering, 23, 399-413 (1981).

Hidalgo, M. D. and García-Encina, P. A., Biofilm development and bed segregation in a methanogenic fluidized bed reactor. Water Research, 36, 3083-3091 (2002).

Hosseini, S. H. and Borghei, S. M., The treatment of phenolic wastewater using a moving bed bioreactor. Process Biochemistry, 40, 1027-1031 (2005).

Iza, J., Fluidized bed reactors for anaerobic wastewater treatment. Water Science \& Technology, 24, (8), 109-132 (1991).

Khan, K. A., Suidan, M. T. and Cross, W. K., Anaerobic activated carbon filter for the treatment of phenol-bearing wastewater. Journal of Water Pollution Control Federation, 53, 151926 (1981).

Kuroda, M., Yuzawa, M., Sakakibara, Y. and Ojamura, M., Methanogenic bacteria adhered to solid supports. Water Research, 22, 653-656 (1988).

Lowry, O. H., Rosebrough, N. J., Farr, R. L. and Randall, R. J., Protein measurement with the folin phenol reagent. Journal of Biological Chemistry, 193, (1), 265-275 (1951).

Marin, P., Alkalay, D., Guerrero, L., Chamy, R. and Schiappacasse, M. C., Design and startup of an anaerobic fluidized bed reactor. Water Science \& Technology, 40, (8), 63-70 (1999).

Moraes, E. M., Adorno, M. A. T., Zaiat, M. and Foresti, E., Determination of volatile acids by gas chromatography in effluent from anaerobic reactors treating liquid and solid wastes (Determinação de ácidos voláteis por cromatografia gasosa em efluentes de reatores anaeróbios tratando resíduos líquidos e sólidos). In: VI Oficina e Seminário Latino-Americano de Digestão Anaeróbia, Recife - PE, Universitária - UFPE, 2, 235-238, (2000). (In Portuguese).

Perez, M., Rodriguez-Cano, R., Romero, L. I. and Sales, D., Performance of anaerobic thermophilic fluidized bed in the treatment of cutting-oil wastewater. Bioresource Technology, 98, 34563463 (2007).

Peterson, G. L., A simplification of the protein assay method of Lowry et. al. which is more generally applicable. Analytical Biochemistry, 83, (2), 346356 (1977).

Qureshi, N., Annous, B. A., Ezeji, T. C., Karcher, P. and Maddox, I. S., Biofilm reactors for industrial bioconversion processes: employing potential of enhanced reaction rates. Microbial Cell Factory, 4, 24 (2005). 
Rajeshwari, K. V., Balakrishnan, M., Kansal, A., Lata, K. and Kishore, V. V. N., State-of-the-art of anaerobic digestion technology for industrial wastewater treatment. Renewable and Sustainable Energy Reviews, 4, 135-156 (2000).

Ramakrishnan, A. and Gupta, S. K., Anaerobic biogranulation in a hybrid reactor treating phenolic waste. Journal of Hazardous Materials, B137, 1488-1495 (2006).

Ripley, L. E., Boyle, W. C. and Converse, L. C., Improved alkalimetric monitoring for anaerobic digestion of high-strength wastes. Journal of Water Pollution Control Federation, 58, (5), 406411 (1986).

Sá, C. S. A. and Boaventura, R. A. R., Biodegradation of phenol by Pseudomonas putida DSM 548 in a trickling bed reactor. Biochemical Engineering Journal, 9, 211-219 (2001).

Saravanan, V. and Sreekrishnan, T. R., Modelling anaerobic biofilm reactors-A review. Journal of Environmental Management, 81, 1-18 (2006).

Saucedo-Terán, R. A., Ramírez-Baca, N., ManzanaresPapayanopoulos, L., Bautista-Margulis, R. and Nevárez-Moorillón, G. V., Biofilm growth and bed fluidization in a fluidized bed reactor packed with support materials of low density. Engineering in Life Sciences, 4, (2), 160-164 (2004).

Speece, R. E., Anaerobic biotechnology for industrial wasterwaters (1st Ed.). Archae Press, Tennessee, USA (1996).

Tavares, C. R. G., Russo, C. and Sant'anna Jr., G. L., Aerobic treatment of wastewaters in a three-phase fluidized-bed bioreactor: A comparison of two types of polymeric supports. Environmental Technology, 15, 687-693 (1994).

Tavares, C. R. G., Sant'anna Jr., G. L. and Capdeville, B., The effect of air superficial velocity on biofilm accumulation in a three-phase fluidizedbed reactor. Water Research, 29, (10), 2293-2298 (1995).

Tay, J. H., He, Y. X. and Yan, Y. G., Improved anaerobic degradation of phenol with supplemental glucose. Journal of Environmental Engineering, $127,38-45$ (2001)

Tziotzios, G., Teliou, M., Kaltsouni, V., Lyberatos, G. and Vayenas, D.V., Biological phenol removal using suspended growth and packed bed reactors. Biochemical Engineering Journal, 26, 65-71 (2005).

Varesche, M. B., Zaiat, M., Vieira, L. G. T., Vazoller, R. F. and Foresti, E., Microbial colonization of polyurethane foam matrices in horizontal flow anaerobic immobilized sludge (HAIS) reactor. Applied Microbiology and Biotechnology, 48, (4), 534-538 (1997).

Veeresh, G. S., Kumar, P. and Mehrotra, I., Treatment of phenol and cresols in upflow anaerobic sludge blanket (UASB) process: a review. Water Research, 39, 154-170 (2005).

Wang, Y. T., Suidan, M. T. and Rittman, B. E., Anaerobic treatment of phenol by an expandedbed reactor. Journal of Water Pollution Control Federation, 58, (3), 227-233 (1986).

WHO, Phenol, Environmental Health Criteria EHC 161, World Health Organization, Geneva (1994). 